\title{
Zintegrowane Centrum Komunikacyjne jako przestrzeń integracji i element ,zszywający" strukturę miasta ${ }^{1}$
}

\author{
Grażyna Dąbrowska-Milewska' ${ }^{1}$ Bartosz Czarnecki²
}

\author{
${ }^{1}$ Katedra Architektury Mieszkaniowej, Wydział Architektury, Politechnika Białostocka, \\ e-mail: g.milewska@pb.edu.pl \\ ${ }^{2}$ Pracownia Urbanistyki i Planowania Przestrzennego, Katedra Architektury Mieszkaniowej, \\ Wydziat Architektury, Politechnika Białostocka,e-mail: b.czarnecki@pb.edu.pl
}

Streszczenie: Centra komunikacyjne znajdujące się często w newralgicznych punktach rozwijających się miast, otoczone arteriami komunikacyjnymi i parkingami, równie często wykazują problemy integracji z otoczeniem. Jednocześnie ze względu na dobrą lokalizację mogą służyć nie tylko podróżnym. Ich infrastruktura komunikacyjna i usługowa, zwłaszcza ta położona na ciągach integrujących części miasta po różnych stronach linii kolejowych, powinna być dostępna także dla innych odbiorców. Centra komunikacyjne będąc węzłami mobilności i aktywności mają olbrzymi potencjał generowania efektów synergicznych. Mogą przyczyniać się do rozwoju terenów sąsiednich i do wzrostu ich atrakcyjności. Opracowując koncepcję ZCK już na etapie wstępnych założeń należy uwzględniać tereny leżące w strefie jego odziaływania, zwłaszcza takie, które przeznaczone są do przekształcania. Na przykładzie 3 projektów nagrodzonych w Konkursie urbanistyczno-architektonicznym na opracowanie koncepcji Zintegrowane Centrum Komunikacji wraz z terenami przyległymi $w$ Białymstoku przedstawiono synergiczne oddziaływanie projektu miejskiego na otoczenie oraz synergiczny wpływ konstrukcji urbanistycznej miasta na projekt miejski.

Słowa kluczowe: zintegrowane centrum komunikacyjne, urbanistyka, konstrukcja urbanistyczna, Białystok.

\section{Wprowadzenie. Centra komunikacyjne jako ośrodki integrujące}

Niezależnie od dyskusji na temat tego czy prymat w planowaniu miast należy przyznać dostępności funkcji czy też mobilności mieszkańców mającej umożliwić im zaspokojenie wszelkiego rodzaju potrzeb, jesteśmy cywilizacją przemieszczania się. Mobilność przybiera różne formy, które stawiają coraz to nowe wyzwania wobec infrastruktury z nią związanej. Obecnie infrastruktura ta, a wśród niej obiekty węzłowe, zaczyna pełnić coraz donioślejszą rolę i w coraz szerszym zakresie.

Początkowo, obiekty współczesnych środków transportu, czyli dworce kolejowe oraz lotniska, powstawały jako obiekty autonomiczne, wyodrębnione, wręcz oddalone od miast. Były one elementami infrastruktury strategicznej, pozostającymi wręcz w domenie zmilitaryzowanej, o czym do dziś świadczą choćby mundury obsługi.

Również sposób funkcjonowania oraz infrastruktura towarzysząca nastawione były w dużej mierze, początkowo może przede wszystkim, na obsługę sfery strategicznej, w tym

1 Materiał opracowany jako część badań finansowanych w ramach projektów badawczych S/WA/2/2016 oraz S/WA/1/2017 realizowanych na Wydziale Architektury Politechniki Białostockiej ze środków MNiSW na naukę. 
transportu towarów. Stąd duże znaczenie infrastruktury służącej obsłudze przewozu poczty, tereny i obiekty składowe oraz magazynowe, infrastruktura wojskowa, które towarzyszyły takim obiektom. Z oczywistych względów obiekty takie podlegały i podlegają ochronie, ustanawiano także na przykład zakaz fotografowania.

Jednak pojawienie się obiektów kolejowych dawało impuls rozwoju przestrzennego miast w kierunku tych ośrodków aktywności. Przykładem może tu być rozwój Białegostoku wzdłuż ciągu dzisiejszej ulicy Św. Rocha w kierunku wzniesionego u progu lat 60. XIX wieku dworca czy rozwój zabudowy i zagospodarowania terenu wzdłuż Alei Żwirki i Wigury w kierunku lotniska na Okęciu w Warszawie - w znacznej mierze już po II wojnie światowej. Jednak infrastruktura kolejowa została najczęściej wchłonięta przez tkankę miejską stając się jej elementem (dworce paryskie czy londyńskie), ale też tam, gdzie nie było specjalizacji dworców oraz środków na kosztowną infrastrukturę (wiadukty, tunele) torowiska wraz z otaczającymi terenami obsługującymi (składy, obiekty techniczne, bocznice), stawała się istotną przeszkodą lub barierą w funkcjonowaniu miasta oraz jego rozwoju przestrzennym (Białystok, Gdańsk, Gdynia).

W miarę wzrostu dostępności podróżowania coraz większe znaczenie uzyskiwały elementy służące obsłudze ruchu pasażerskiego, powodując pojawianie się różnych rozwiązań ukierunkowanych na poprawę dostępności, bezpieczeństwa oraz komfortu podróżnych (poza budynkami dworców: kładki nad torami, przejścia podziemne, podjazdy, parkingi, przystanki transportu publicznego, podstawowe usługi, infrastruktura informacyjna).

Z czasem jednak, wraz ze zmianami znaczenia poszczególnych środków transportu oraz komunikacji w ogóle, zaczęła zmieniać się sama koncepcja funkcjonowania infrastruktury kolejowej, a także jej znaczenie w strukturze miasta[1]. Zaczęły następować procesy ucywilniania, a nawet w niektórych krajach prywatyzacji kolei i jej infrastruktury, przynajmniej w części związanej z taborem i świadczeniem usług przewozowych. Wobec spadku znaczenia przewozów masowych, zaczęto redukować zasoby terenów i obiektów kolejowych. Często wprowadzono kryterium rentowności w ocenie funkcjonowania kolei i jej obiektów, co spowodowało uwolnienie potencjału komercyjnego terenów oraz obiektów kolejowych, o czym niżej.

W związku z powyższymi procesami funkcję i znaczenie obiektów kolejowych zaczęto postrzegać nie jako ostatniego punktu podróży do miasta i miejsca, gdzie zaczyna się podróż po mieście (lub odwrotnie). Z jednej strony pojawiła się koncepcja hube'a - obiektu - dobrym określeniem jest pojęcie terminal - który jest etapem w podróży, w której następuje przesiadka pasażerów w różnych kierunkach (lub przeładunek towarów) i zaczyna się nowa podróż. Wiąże się to także z koncepcjami multimodalności oraz intermodalności, czyli zaplanowanym, złożonym wykorzystaniem sekwencji różnych środków transportu i/lub operatorów/ przewoźników, w celu skrócenia czasu przewozu/podróży, poprawy efektów ekonomicznych itd. Takie podejście wymaga odpowiedniego połączenia na terenie obiektu różnych środków transportu. Oczywiście nawet pierwsze dworce łączyły w pewien sposób różne środki transportu: następowała przesiadka z pojazdu dalekobieżnego na lokalny środek transportu. Jednak w węzłach czy hube'ach komunikacyjnych mamy do czynienia z wieloma możliwościami zmiany środka transportu w ramach tego samego rodzaju transportu lub wśród różnych rodzajów (przesiadka z szybkiego pociągu, na pociąg dalekobieżny, albo na pociąg regionalny, na pociąg podmiejski, na szybką kolej miejską, na różne zbiorowe środki transportu miejskiego, wreszcie na indywidualne środki transportu (głównie samochody). Zdarzają się także dworce zintegrowane z lotniskami lub z przystaniami promowymi (Amsterdam). Podobną rolę, tyle że swoistych hube'ów w relacji miasto-region miejski pełnią końcowe stacje środków transportu miejskiego zintegrowane z parkingami strategicznymi oraz ewentualnie innymi jeszcze 
funkcjami w ramach koncepcji park-and-ride. $Z$ drugiej strony dworce, znajdujące się często w newralgicznych punktach rozwijających się miast, zostały otoczone arteriami komunikacyjnymi i parkingami. Pojawił się zatem problem ich integracji z otaczającą przestrzenią miasta. Zaczęto wprowadzać systemy pieszych tuneli podziemnych, mające zapewnić bezpieczne, bezkolizyjne przedostanie się podróżnych przez obszerne połacie powierzchni manewrowo-przystankowo-parkingowych oraz otaczające arterie (Warszawa Centralna, Warszawa Zachodnia, Gdańsk Główny i in). Przestrzenie te z czasem ujawniły potencjał komercyjny: stanowią potencjalne mall'e, jako miejsca o intensywnym ruchu pieszych, zapewniające osłonę przed warunkami atmosferycznymi, mogą z powodzeniem spełniać rolę przestrzeni usługowych. Ze względu na znakomite lokalizacje, służą one nie tylko podróżnym. Infrastruktura komunikacyjna i usługowa, zwłaszcza ta położona na ciągach integrujących części miasta po różnych stronach linii kolejowych, została otwarta nie tylko na podróżnych ale także na innych odbiorców. Jakże to odmienna formuła funkcjonowania od tej z czasów gdy w celu wejścia do wielu części dworców należało okazać ważny bilet na przejazd pociągiem odpowiedniej klasy lub peronówkę! Stąd już blisko do nowej formuły dworca jako wielofunkcyjnego kompleksu łączącego różne rodzaje infrastruktury komunikacyjnej (w tym służącą korzystaniu z komputerów oraz Internetu) z wszelkiego rodzaju usługami, a nawet wręcz centrami usługowymi, z ich wszelkimi atrybutami (parkingi wielopoziomowe) oraz różnorodnością oferty. Rozwiązania przyjmowane są tu różne. Można podać przykłady kompleksu usługowo-komunikacyjnego w Utrechcie, a zwłaszcza dworca kolejowego w Lipsku w Saksonii, gdzie w niezwykle kulturalny sposób, nie burząc hierarchii znaczeń i rangi dworca, niegdyś o największej ponoć hali w Europie, wprowadzono pod ziemię dwa poziomy centrum usługowego.

a)

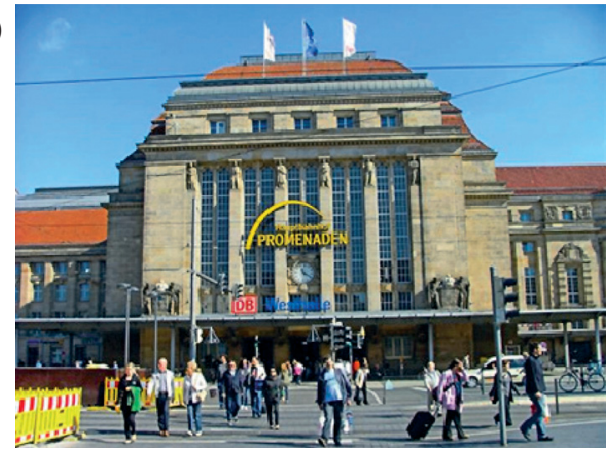

b)

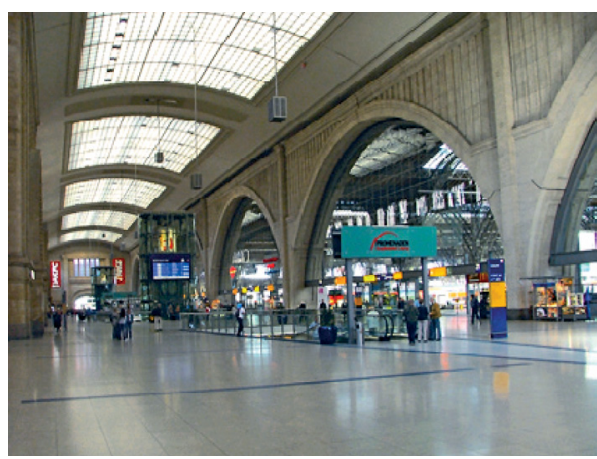

Rys. 1 a i b. Budynek dworca w Lipsku oraz wnętrze hali głównej z widocznym zejściem na poziomy centrum handlowego; źródło: fot. B. Czarnecki

Niestety wśród polskich inwestycji w infrastrukturę dworcową częste są przypadki takiej przebudowy dworców, w wyniku której tracą one swoją rangę oraz ekspozycję w przestrzeni miasta i stają się w istocie dodatkami do centrum handlowego (Poznań, Kraków, Katowice). Niemniej, znaczne wzbogacenie programu funkcjonalnego przywraca znaczenie i podnosi atrakcyjność, zwłaszcza funkcjonalną, kompleksów dworcowych, przyciągając do nich większą liczbę zróżnicowanych pod względem oczekiwań odbiorców. Jednocześnie następująca redukcja powierzchni terenów kolejowych niezwiązanych z bezpośrednią obsługą ruchu, pozwalająca na inny sposób ich zagospodarowania, zbliża miasto do węzła komunikacyjnego, czyniąc z całości czynnik integrujący nie tylko użytkowników, ale i otaczające struktury miasta dotąd często rozdzielone terenami kolejowymi $[2,3,4,5,6]$. 


\section{Zintegrowane Centrum Komunikacyjne w Białymstoku - jako miejsce integracji ,zszywające" struktury miasta - w projektach konkursowych}

\subsection{Centrum komunikacyjne w strategii rozwoju urbanistycznego}

Tworzenie centrów komunikacyjnych, które integrują różne środki transportu, a ponadto są łączone z funkcjami handlowymi, kulturalnym, administracyjnymi czy rekreacyjnymi, staje się standardem w strategiach rozwojowych miast o znaczeniu regionalnym. Te kosztowne i skomplikowane pod względem realizacyjnym inwestycje, mające wpływ na jakość życia mieszkańców, sprawność funkcjonowania miasta i jego wizerunek, należą do flagowych projektów miejskich. I jako takie muszą być bardzo dobrze przygotowane pod względem programowym, biznesowym, marketingowym, a także pod względem projektowym.

Zintegrowane Centra Komunikacyjne (ZCK) są węzłami mobilności i aktywności, czyli tymi elementami struktury sieciowej miasta, które mają olbrzymi potencjał generowania efektów synergicznych. Mogą przyczyniać się do rozwoju terenów sąsiednich i do wzrostu ich atrakcyjności. W strategiach urbanistycznych nie powinny być zatem traktowane jak „wyspy” wyalienowane z otoczenia. Dlatego ważne jest, aby już na etapie wstępnych koncepcji ZCK, w zakresie opracowania uwzględniać tereny leżące w strefie jego odziaływania, zwłaszcza takie, które w dokumentach planistycznych wskazane zostały jako przeznaczone do przekształcania. W początkowych fazach konkretyzowania założeń projektu przebudowy obszarów przydworcowych sprawa zasadnicza jest dopasowanie struktury programowo- przestrzennej projektowanych przedsięwzięć do rzeczywistych uwarunkowań danego obszaru, a zwłaszcza rozpoznanie potrzeb społecznych i takie zdefiniowanie problemów projektowych, aby zastosowane rozwiąania techniczne i ekonomiczne uwzględniały również kryteria stużace ochronie dóbr publicznych [7].

Argumentem za stosowaniem powyższych zasad jest nie tylko antycypowany efekt „dźwigniowy”, który może mieć wpływ na planowany sposób zagospodarowania „przekształcanego" terenu, ale także - a może przede wszystkim - dążenie do osiągnięcia spójności i ciągłości przestrzeni miejskiej.

Przykładem takiego podejścia do problemu jest Konkurs urbanistyczno-architektoniczny na opracowanie koncepcji Zintegrowanego Centrum Komunikacji wraz z terenami przyległymi w Białymstoku, zorganizowany w 2012 roku przez Urząd Miejski w Białymstoku.

Celem konkursu, który określono jako ideowy, było uzyskanie:

- propozycji programowo - przestrzennej Zintegrowanego Centrum Komunikacyjnego (ZCK) mieszczącego dworce: kolejowy i autobusowy, w połączeniu z obsługą środkami transportu miejskiego,

- koncepcji urbanistycznej i planu zagospodarowania obszaru obejmującego strefę projektowanego ZCK wraz z terenami przyległymi, z uwzględnieniem planowanych docelowych rozwiązań komunikacyjnych. Zaznaczono, że od koncepcji oczekuje się przedstawienia wizji architektoniczno - urbanistycznej wskazującej kierunki przekształceń przestrzennych tego fragmentu miasta [8].

W rezultacie tak sformułowanych zadań uzyskano spójne koncepcje projektowe, w których ZCK było częścią większej całości urbanistycznej i w których szczególny nacisk położony został na kwestie powiązań ZCK ze strukturami miasta. W tym przypadku o tyle istotnymi, że białostocki węzeł komunikacyjny (kolejowo-autobusowy) zlokalizowany jest na pograniczu śródmieścia i terenów wskazanych do przekształcenia, a jego infrastruktura kolejowa skuteczne te dwa tereny rozdziela. Aktualnie dworce autobusowy i kolejowy znajdują się po 
przeciwległych stronach torów i połączone są dwiema kładkami pieszymi niedostosowanymi do użytkowania przez osoby z niepełnosprawnością.

\subsection{Analiza porównawcza prac nagrodzonych w Konkursie urbanistyczno- architektonicznym na opracowanie koncepcji Zintegrowanego Centrum Komunikacji wraz z terenami przyleglymi w Bialymstoku}

Przedmiotem analizy porównawczej są 3 nagrodzone projekty, które zdaniem Jury najlepiej spełniły założenia i cele Konkursu, a zdaniem Autorów niniejszego tekstu, wnoszą istotny wkład do dyskusji nad formułą programową i kształtem przyszłego Centrum.

W analizie koncentrowano się na następujących zagadnieniach: 1) programie funkcjonalnym ZCK, a zwłaszcza relacjach pomiędzy funkcjami dworcowymi a komercyjnymi; 2) rozwiązaniach urbanistyczno-architektonicznych zespołu ZCK, a zwłaszcza ukształtowaniu przestrzeni publicznych; 3)proponowanych kierunkach przekształceń terenów przydworcowych; 4) elementach sprzyjających integracji dwóch części miasta rozdzielonych koleją.

Wyjaśnienie pojęć i nazewnictwa używanych w tekście:

- Obszar - obszar objęty opracowaniem konkursowym ograniczony ulicami: Bohaterów Monte Cassino, Łomżyńską, Mikołaja Kopernika, Konduktorską, Leona Kruczkowskiego, projektowanym przebiegiem pasa drogowego 6KDG obejmującego fragment estakady, Al. Solidarności oraz Knyszyńską, Wiatrakową, Wysoką i Poleską w Białymstoku. Strukturalnie obszar podzielony jest linią kolejową na dwie części;

- Nowa Dzielnica - teren na zachód od linii kolejowej, ograniczony Al. Solidarności i projektowanym przebiegiem pasa drogowego $6 \mathrm{KDG}$;

- zespół ZCK - obejmuje wszystkie obiekty zaprojektowane na terenie oznaczonym w danym projekcie jako Teren Zintegrowanego Centrum Komunikacyjnego (ten zaś zawiera się w pasie wyznaczonym przez ul. Bohaterów Monte Cassino, projektowana trasą 6KDG, ul. Kolejową, wiaduktem Dąbrowskiego).

- funkcje dworcowe - funkcje komunikacyjne zintegrowane z funkcjami obsługi pasażerów (kasy, informacja, poczekalnie, toalety) i drobnymi usługami komercyjnymi (gastronomia, handel) ukierunkowanymi na potrzeby podróżnych.

\section{Praca 1. Autorzy: Pracownia WXCA [9].}

Ze wszystkich prac konkursowych ta wyróżnia się pozytywnie rozumianą ,zachowawczością” i „tradycyjnością” zarówno w stosunku do zastanej tkanki architektonicznej, jak i rozumienia roli centrum komunikacyjnego i jego miejsca w strukturze miasta. Spostrzeżenia powyższe potwierdzają deklaracje Autorów: Celem projektu jest wydobycie wartościowych cech istniejacych układów przestrzennych w obrębie zadanego obszaru oraz zaproponowanie nowych: dopetniajacych je i spajajacych, oraz wiażacych z obszarami przylegtymi. Poprzez zachowanie $i$ dopetnienie istniejących układów pragmatyczna struktura współczesnego miasta możliwie jest stworzenie koncepcji opierajacej się na szacunku do charakteru tego miejsca, połaczonej ze śmiałym, przyszłościowym działaniem [9].

\section{Koncepcja Zintegrowanego Centrum Komunikacyjnego}

Konsekwencją „zachowawczego” podejścia były decyzje: pozostawienie funkcji dworcowych w miejscu, które je pełni od 150 lat (czyli w zabytkowym budynku dworca kolejowego przy ul. Kolejowej); adaptacja i rozbudowa dworca PKS z lat 70. XX wieku; zachowanie wielu obiektów o charakterze magazynowym i usługowym związanych z koleją i lokalnym przemysłem, niekoniecznie wpisanych do ewidencji zabytków czy uznanych za dobra kultury współczesnej. 
a)

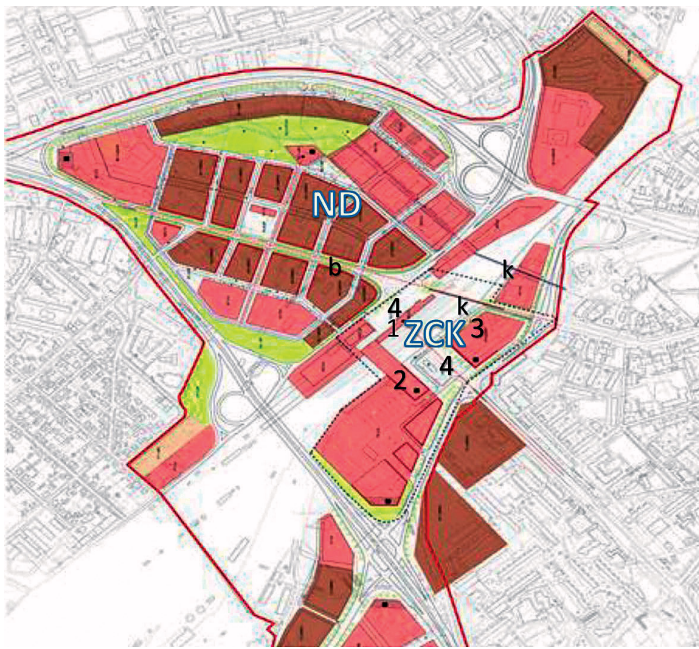

ZcK - obszar Zintegrowanego Centrum Komunikacyjnego: 1. Budynek historycznego dworca PKP

2.Nowy dworzec autobusowy zintegrowany z kolejowym

3.Obiekty komercyjne

4. Plac

$\mathrm{k}$-kładki pieszo-rowerowe

ND - Nowa Dzielnica, mix development

b - bulwar, kontynuacja historycznej osi śródmiejskiej

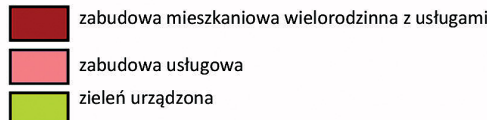

b)

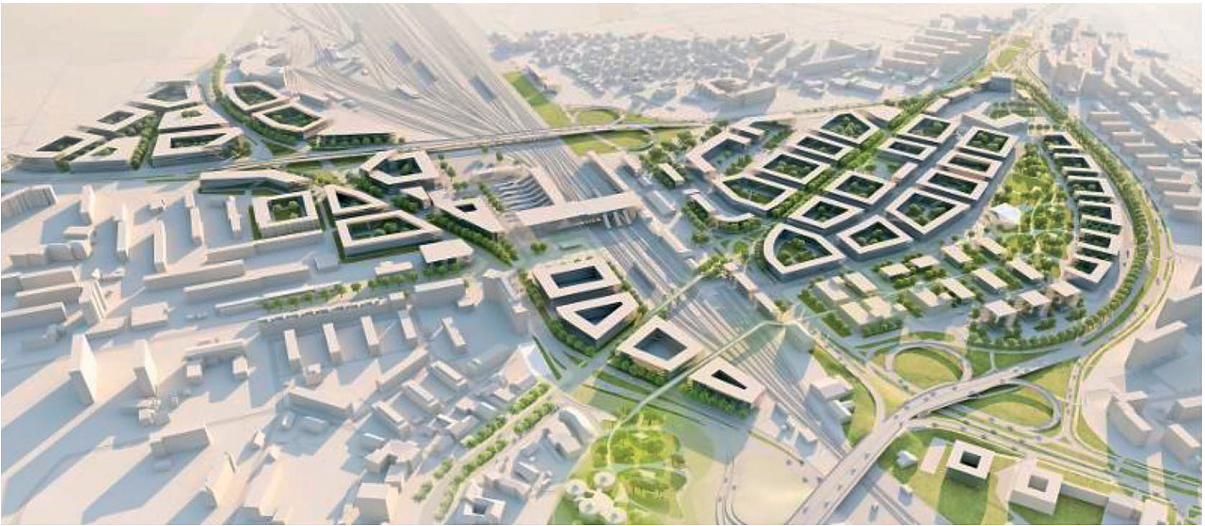

c)

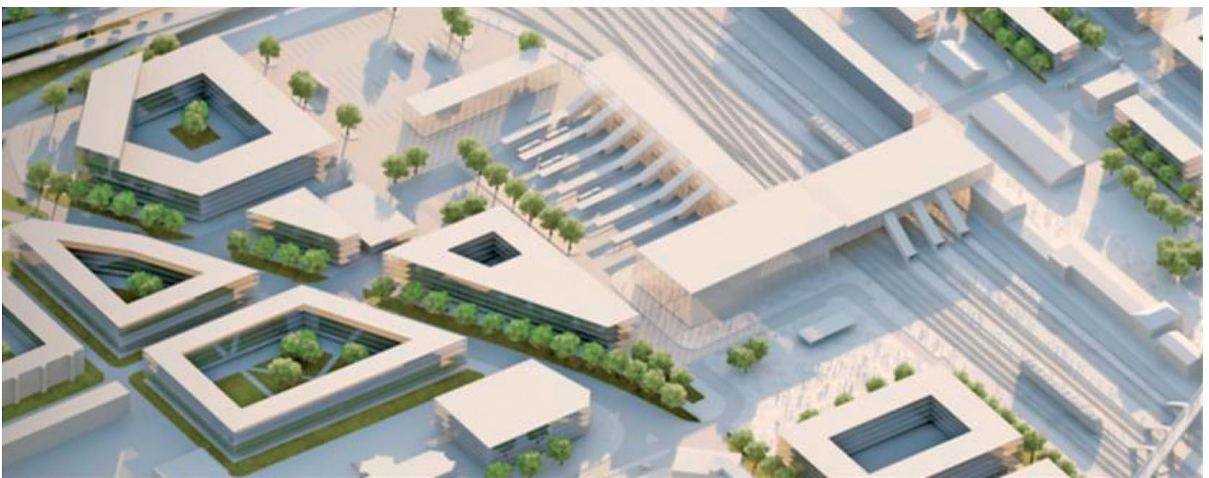

Rys. 2a,b,c Praca Nr 1: a) plan zagospodarowania Obszaru; b) koncepcja urbanistyczna Obszaru; c) koncepcja urbanistyczna ZCK

Koncepcja funkcjonalno-przestrzenna ZCK ma niewiele wspólnego ze współczesną tendencją łączenia wielu funkcji ,pod jednym dachem” w mega-strukturze zajmującej niekiedy kilka kwartałów. Jest raczej jej antytezą, zakłada bowiem oddzielenie przestrzenne funkcji dworcowych (związanych z komunikacją i obsługą pasażerów) od funkcji komercyjnych 
(handlowych, usługowych, kulturalnych, rozrywkowych, biurowych, itd.). Znajduje to wyraz w koncepcji przestrzennej zespołu, składającego się z odrębnych części (brył) niezależnie dostępnych z przestrzeni publicznej. Funkcje dworcowe znajdują swoje miejsce w budynkach dworców (przebudowanym dworcu PKS połączonym pasażem z historycznym dworcem PKP), a funkcje komercyjne w projektowanych kwartałach miejskiej zabudowy. Powyższe rozwiązanie jest konsekwencją zasady przyjętej dla całego obszaru dzielnicy: stosowania zabudowy kwartałowej o miejskim charakterze, z wyraźnie wyartykułowanymi pierzejami.

Ciekawym konceptem ideowym jest nazwanie „osią biznesu” koncentracji zabudowy o przeznaczeniu komercyjnym wzdłuż ulicy Bohaterów Monte Cassino. Dzięki swojej lokalizacji w bezpośrednim sasiedztwie dworca (...) harmonijnie wpleciona $w$ istniejaca strukture miasta (...) nowoczesna ulica z przeważajaca funkcja biurowo - handlowa wptynie korzystnie zarówno na wizerunek miasta, jak i na jego rozwój ekonomiczny [9].

Układ przestrzeni publicznych zespołu ZCK definiują: ulica B. Monte Cassino i dwa place, leżące po przeciwnych stronach torów. Plac od strony obwodnicy śródmiejskiej odsłania elewację zabytkowego dworca kolejowego, a dzięki usytuowaniu na osi ul. Wyszyńskiego, czyni ją widoczną z dalekiej perspektywy. Dwie równoległe ściany placu utworzone są przez proste budynki: nowego dworca PKS oraz komercyjnego centrum handlowego. W rejonie placu zlokalizowano postój taxi, pawilon informacyjny i parking na rowery. Plac po drugiej stronie torów, przed zabytkowym dworcem przy ulicy Kolejowej, jest zwornikiem między ZCK a Nową Dzielnicą. Wyznaczają go pierzeje wchłaniające istniejące budynki oraz nowa zabudowa dzielnicy. Podobnie jak w poprzednim wydzielono w nim miejsce na postój taxi i parking rowerowy. Pod płytami obu placów zaprojektowano parkingi samochodowe.

Odnosząc się do kwestii ,zintegrowania” funkcji w ramach ZCK, trzeba stwierdzić, że pełna integracja występuje tylko w zakresie funkcji komunikacyjnych i związanych z obsługą pasażerów. Ma ona miejsce w kompleksie dworcowym, który wyposażony jest w usługi związane z obsługą pasażerów (lokale gastronomiczne, handlowe, poczekalnie, kasy). Kluczowym elementem kompleksu integrującym funkcje komunikacyjne jest obszerny pasaż przerzucony nad torami kolejowymi i jego prostopadła odnoga w strefie dworca PKS; dzięki schodom ruchomym ułatwia on przemieszczanie się podróżnych między peronami kolejowymi i stanowiskami autobusów. Ze względu na dostępność pasaż jest też formą przestrzeni publicznej łączącej dwie strony miasta.

\section{Kierunki przekształceń obszaru przylegającego do ZCK}

W przedstawionej propozycji, tereny leżące na zachód od linii kolejowej docelowo przeznaczono na Nową Dzielnicę miejską, o wyważonych proporcjach pomiędzy funkcjami: mieszkaniowymi, rekreacyjnymi, usługowymi i biurowymi. Relatywnie duży udział terenów związanych z przestrzeniami innowacyjności, wynika z planowanej adaptacji zespołu budynków poprzemysłowych na park technologiczny. W układzie urbanistycznym dzielnicy zachowano ciągłość miejskiego systemu przestrzeni publicznych i terenów zielonych. Osią układu jest ulica Zwycięstwa, kontynuująca historyczną oś śródmiejską, która staje się miejskim, zadrzewionym bulwarem. (Realizacja docelowego układu drogowego diametralnie zmienia sytuację w tej części miasta, powodując zmniejszenie ruchu na ul. Zwycięstwa, co umożliwia przekształcenie jej w trakt komunikacyjny o bardziej reprezentacyjnych, rezydencjalnym lub rekreacyjnym, charakterze). W połowie długości bulwaru, w środku ciężkości obszaru dzielnicy, zlokalizowano plac publiczny. Otoczony zabudową z usługami, może być wykorzystywany do lokalnych imprez lub jako plac targowy. Miejsce to ma rangę węzła w strukturze sieciowej miasta. Podobnie jak na znajdującym się w strefie śródmiejskiej terenie ZCK, projektowana struktura urbanistyczna zabudowy bazuje na formule kwartału. 
Zachowanie wspólnej zasady w tym zakresie z pewnością wzmocni efekt ciągłości i spójności z przestrzenią ,za torami”.

Powiązania ZCK z otoczeniem i Obszaru z układem śródmiejskim. Projekt zawiera następujące elementy połączenia terenów po obu stronach torów kolejowych, sprzyjające integracji wschodniej i zachodniej części miasta:

1) połączenie ulic Św. Rocha i Zwycięstwa szeroką kładką pieszo-rowerową dostosowaną do osób z niepełnosprawnością,

2) powiązanie kładką pieszo-rowerową obszarów zieleni zlokalizowanych po przeciwnych stronach torów kolejowych: parku im. J. Dziekońskiej u stóp wzgórza kościoła Św. Rocha, z projektowanym ciągiem zielonym parku naukowo-technologicznego, powiązanego dalej z parkiem Nowej Dzielnicy,

3) powiązanie dworców kolejowego i autobusowego obszernym pasażem przewieszonym nad peronami kolejowymi, który może stać się atrakcyjną przestrzenią publiczną łączącą obie strony miasta.

4) przedłużenie historycznego i funkcjonalnego „kręgosłupa” miasta (ciągu ulic: Rynek Kościuszki, Lipowa, Św. Rocha) o ulicę Zwycięstwa, zaplanowaną w konwencji atrakcyjnego, miejskiego bulwaru.

\section{Praca 2. Autorzy: Biuro Architektoniczne 22Architekci [10]}

W odróżnieniu od pracy nr 1, stawiającej na harmonijne wpisanie centrum komunikacyjnego w strukturę urbanistyczną złożoną z kwartałów, ta praca nastawiona jest na stworzenie całkowicie nowej jakości przestrzennej i funkcjonalnej na styku centrum Białegostoku i jego dzielnic mieszkalnych oraz na wyróżnienie obiektu ZCK z otoczenia poprzez nadanie mu cech ikonicznych [10]. Wynika to z założenia, że jest ono nie tylko kluczowym węzłem komunikacyjnym miasta i ważnym węzłem aktywności, ale także zwornikiem układu urbanistycznego, ogniwem łączącym śródmieście z obszarem po drugiej stronie torów, przekształcanym w nowa dzielnicę miejską.

\section{Koncepcja Zintegrowanego Centrum Komunikacyjnego.}

Zaproponowana koncepcja wskazuje, że u jej podstaw legły następujące decyzje: 1) przeniesienie funkcji dworca kolejowego na stronę wschodnią torów (i wykorzystanie historycznego budynku dworca na inne cele); 2) adaptacja i przebudowa istniejącego dworca PKS; 3) przyjęcie modelu pełnego zintegrowania funkcji dworcowych z funkcjami komercyjnymi; 4) podkreślenie znaczenia miejsca poprzez dominantę wysokościową.

Budynek główny ZCK, skupiający funkcje dworcowe i komercyjne, został zlokalizowany po wschodniej stronie torów, w strefie śródmiejskiej, wzdłuż ulicy Bohaterów Monte Cassino (będącej częścią obwodnicy) zapewniającej podłączenie do systemu komunikacji miejskiej. Plac wejściowy do ZCK ma formę podcienia skrywającego pod dachem podjazd dla autobusów miejskich oraz taksówek oraz wejścia do części dworcowej i komercyjnej. O parametrach obiektu niech świadczy długość elewacji frontowej - wynosząca ok. $300 \mathrm{~m}$.

Część dworcową zespołu tworzy zaadaptowany budynek dworca PKS i „doklejona” do niego hala nowego dworca PKP z antresolą na poziomie +1 . Antresola łączy się z platformą rozprowadzającą ruch podróżujących na perony kolejowe (za pomocą ruchomych schodów) i mieszczącą wszelkiego typu funkcje pierwszej potrzeby dla pasażerów. Po drugiej stronie torów platforma przechodzi ponad jednokondygnacyjną częścią starego budynku dworcowego i kończy swój przebieg na Placu dworcowym, sprowadzając ruch windą i schodami ruchomymi umieszczonymi w nowoczesnej, transparentnej bryle. Platforma jest zatem kluczowym, wewnętrznym elementem ZCK łączącym obie strony miasta. Do strefy dworcowej przylegają zadaszone perony kolejowe i autobusowe. 


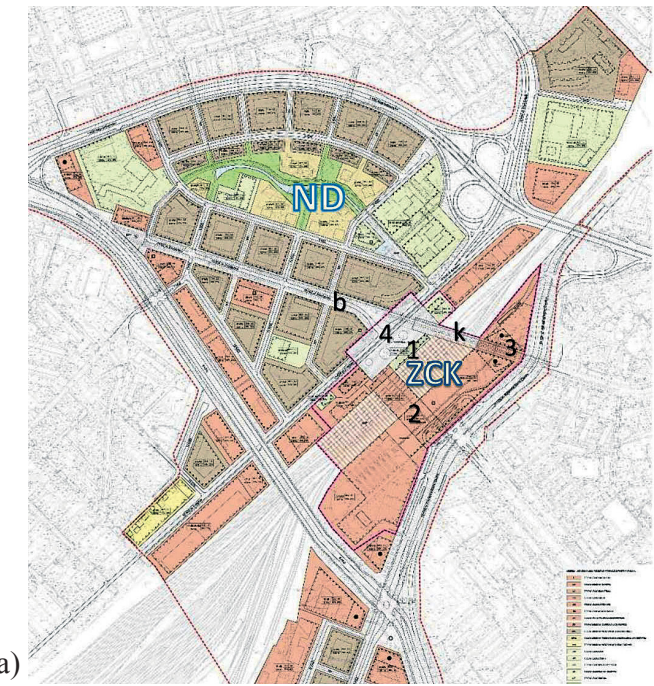

ZCK - obszar Zintegrowanego Centrum Komunikacyjnego: 1. Budynek historycznego dworca PKP

2.Nowy dworzec kolejowy i autobusowy zintegrowany z komercyjnym centrum handlowo-rekreacyjno-biurowym 3.Dominanta-Brama Dworcowa

4. Plac

$\mathrm{k}$-kładki pieszo-rowerowe

ND - Nowa Dzielnica, mix development

b - bulwar handlowy, kontynuacja historycznej osi śródmiejskiej

a)

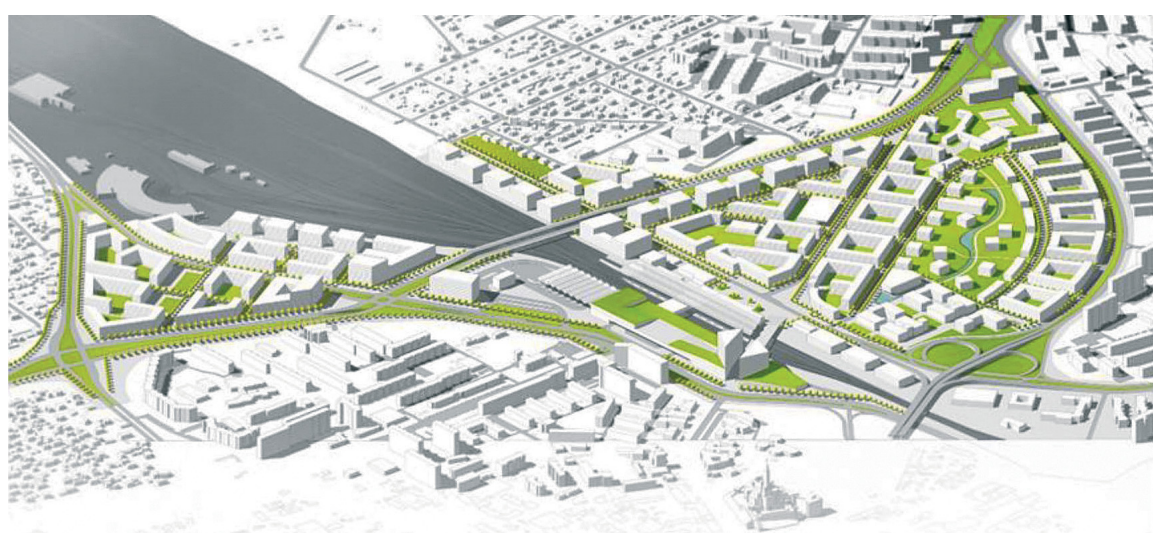

b)

$\square$ zabudowa mieszkaniowa wielorodzinna z usługami
$\square$ zabudowa usługowa
$\square$ zieleń urządzona

c)

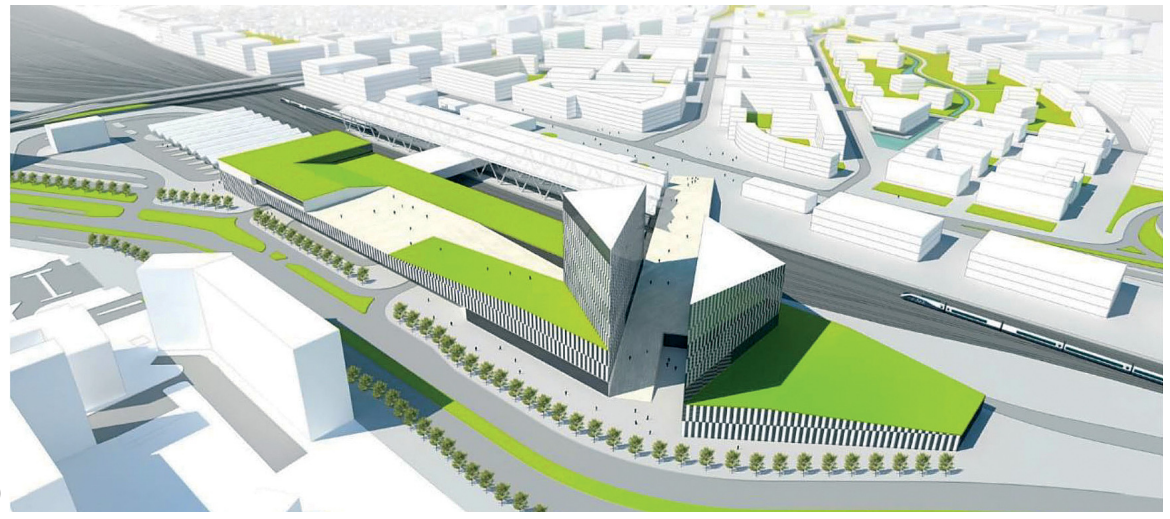

Rys. 3a,b,c. Praca Nr 2: a) plan zagospodarowania terenu z głównymi elementami koncepcji ZCK; b) koncepcja urbanistyczna całego obszaru; c) koncepcja urbanistyczna ZCK

Część komercyjna obiektu składa się z 3-kondygnacyjnej galerii handlowo-usługowo-rozrywkowej, dwóch 15-kondygnacyjnych budynków biurowych (tworzących Bramę) oraz 
wielosalowego kina. Na dwóch pierwszych poziomach, na których istnieje przenikanie ze strefą dworcową, dominują funkcje: handlowa i gastronomiczna. Na poziomie +2 znajduje się też kino połączone z częścią handlową przejściem pod kładką. Na trzeciej kondygnacji umieszczono: zespół sport i fitness oraz klub rozrywkowy, a między nimi - taras użytkowy dla gości kompleksu. Część podziemną obiektu zajmują parkingi na potrzeby pasażerów, użytkowników, klientów galerii i pracowników biur.

Pod względem typologicznym zaproponowana koncepcja ZCK niewątpliwie wpisuje się w nurt tworzenia struktur wielofunkcyjnych ,pod jednym dachem”, w których dworce są raczej dodatkiem do przestrzeni komercyjnych. Świadczą o tym proporcje pomiędzy powierzchniami dworcowymi a komercyjnymi przedstawiające się jak 1:6, w tym w odniesieniu do powierzchni handlowych jak 1:3.

W kompozycji urbanistycznej zespołu punktem węzłowym, spinającym Nową Dzielnicę ze śródmieściem, jest przejście Osi przez budynek główny, podkreślone dwiema wieżami biurowymi tworzącymi Bramę Dworcową. Jest ona o 30m niższa od wieży kościoła

św. Rocha, więc nie będzie wchodzić w konflikt z tą dominantą. Pomiędzy wieżami wznosi się szeroka kładka pieszo-rowerowa, prowadząca ponad torami na Plac Dworcowy i ulicę Zwycięstwa. Forma obiektu jest na tyle charakterystyczna, że ma szansę stać się znakiem rozpoznawczym ZCK, co nie jest bez znaczenia w strategii marketingowej.

Znajdujący się po drugiej stronie torów zabytkowy dworzec, wraz z sąsiednimi zabudowaniami staje się Centrum Kulturalnym z galeriami sztuki, klubami, pubami, restauracjami. Plac Dworcowy zmienia swój charakter; zamiast parkingu jakim był do tej pory staje się miejskim placem pieszym z elementami małej architektury i zieleni, przestrzenią ekspozycji, miejscem odpoczynku, kultury i rozrywki - salonem Białegostoku.

\section{Kierunki przekształceń Obszaru przylegającego do ZCK}

Podobnie jak w poprzedniej pracy, tereny leżące na zachód od linii kolejowej docelowo przeznaczono na Nową Dzielnicę, która spina funkcjonalnie sąsiadujące osiedla, łącząc je zarazem - za pomocą szeregu atrakcyjnie zaprojektowanych przestrzeni publicznych (w tym przejścia efektowną kładką przez ZCK) - z centrum Białegostoku. Kręgosłupem założenia jest przedłużenie historycznej osi miasta, czyli ciąg ulic Św. Rocha-Zwycięstwa-Jana Pawła II. Ulica Zwycięstwa-stanie się miejska, tętniąca życiem ulica o niewielkiej intensywności ruchu kołowego, nasycona funkcjami handlowymi i ustugowymi [10]. Mniej więcej w środku tej ulicy zaplanowano halę targową wraz z zadaszonym placem.

Teren północny pomiędzy ul. Zwycięstwa a Aleją Solidarności przeznaczony jest głównie pod zabudowę mieszkaniową wielorodzinną, która przechodzi ze zwartych struktur pierzejowych przy ulicach w niską zabudowę punktową przy wewnętrznym parku. Przy nim zlokalizowane są istniejące obiekty edukacji (Zespół Szkół Ponadgimnazjalnych oraz Wyższa Szkoła Ekonomiczna), projektowany Dom Kultury i Kampus Naukowy zaplanowany $\mathrm{w}$ adaptowanym zespole poprzemysłowym.

Powiązania ZCK z otoczeniem i Obszaru z układem śródmiejskim. Projekt zawiera następujące elementy połączenia terenów po obu stronach torów kolejowych, sprzyjające integracji wschodniej i zachodniej części miasta:

1) połączenie ul. Św. Rocha z Placem Dworcowym i ul. Zwycięstwa szeroką kładką pieszo-rowerową przerzuconą pomiędzy Brama Dworcową,

2) powiązanie budynku głównego ZCK z Placem Dworcowym obszernym pasażem przewieszonym nad peronami kolejowymi,

3) przedłużenie historycznego i funkcjonalnego „kręgosłupa” miasta (ciągu ulic: Rynek Kościuszki, Lipowa, św. Rocha) o ulicę Zwycięstwa, zaplanowaną w konwencji żyjącej ulicy, nasyconej programem handlowo-usługowym. 


\section{Praca nr 3. Autorzy: MACIEJ KURYLOWICZ - ARCHITEKT [11]}

Praca cechuje się wyrazistą ideą i śmiałymi decyzjami projektowymi. Autorzy zaproponowali radykalne rozwiązanie: przykrycie torowiska wyniesioną płytą na odcinku od planowanej estakady aż do wiaduktu ul. Dąbrowskiego. W ten sposób zlikwidowali barierę dzielącą miasto i odzyskali cenny teren śródmiejski. Jego wykorzystanie na przestrzenie publiczne, sprzyjające przemieszczaniu się, może być spoiwem dotychczas rozdzielonych stron. W projekcie konkursowym zaproponowano tu tereny rekreacyjne, co jest konceptem dość dyskusyjnym ze względu na nierentowność inwestycji, ale o tyle trafnym, że park stanowić będzie przedłużenie już istniejących terenów zielonych Parku im. J. Dziekońskiej i wzgórza Św. Rocha. Ponadto w czasach Branickiego w pobliżu znajdowały się parki Dużej i Małej Kaskady, co może być wykorzystane w marketingu miejskim jako element historycznej reminiscencji. Decyzja o zastosowaniu platformy, wyznaczającej nowy poziom przestrzeni publicznej, miała istotny wpływ na rozwiązania ZCK.

\section{Koncepcja Zintegrowanego Centrum Komunikacyjnego}

W projekcie przyjęto pełne zintegrowanie funkcji komunikacyjnych i związanych z obsługą pasażerów oraz częściowe zintegrowanie z funkcjami komercyjnymi. Główne funkcje - dworce kolejowy i autobusowy - umieszczono w jednej 2-kondygnacyjnej, podłużnej bryle, ustawionej poprzecznie do układu torowego i nad nim „przewieszonej”. Łączy ona na zasadzie mostu obie strony miasta i rozprowadza ruch na perony za pomocą ruchomych schodów. Dojście do peronów możliwe jest też od strony parku, z placu na osi ul. Św. Rocha. Przestrzenie związane z obsługą pasażerów wzbogacone są o przestrzenie komercyjne (usługi, handel, gastronomię) w zakresie wystarczającym dla funkcjonowania obiektu.

Lokalizacja nowego dworca w miejscu zajmowanym przez istniejący dworzec PKS nie koliduje z istniejącą infrastrukturą dworca, a bliskość obwodnicy śródmiejskiej i projektowanej estakady ułatwia połączenie infrastruktury ZCK z układem drogowym miasta i zapewnia sprawną obsługę w zakresie transportu indywidualnego i zbiorowego

Uzupełnieniem programu funkcjonalnego ZCK są połączone w sposób bezpośredni z bryłą dworca: 1) Centrum Kongresowe, przeznaczone na funkcje wystawiennicze i konferencyjne, przygotowane do obsługiwania imprez typu expo, targi o charakterze ponadregionalnym; 2) budynek historycznego dworca, przeznaczony na strefę food court, dostępny również z przestrzeni miejskiej; 3) pasaż handlowy (1-kondygnacyjny, pod platformą) łączący dworzec z budynkiem biurowym przy ul. Bohaterów Monte Cassino. Dwie najniższe kondygnacje budynku biurowego przeznaczono na funkcje handlowe, pozostałe - w intencjach Autorów- mogą służyć połączonej administracji lokalnej i regionalnej. Pokaźna kubatura tego obiektu, nawiązująca wysokością do 11-kondygnacyjnego budynku galeriowego po drugiej stronie ulicy, jest istotnym komponentem układu przestrzennego zespołu. Wszystkie obiekty ZCK korzystają ze wspólnego zaplecza parkingowego (naziemnego parkingu wielopoziomowego i park+ride). Obsługuje ono także budynek Aquaparku zaplanowany przy ul. Kolejowej po stronie Nowej Dzielnicy.

Przestrzenie publiczne w zespole ZCK zdefiniowane są przez prostą bryłę dworca, która tworzy wspólną ścianę dla położonych na różnych poziomach placów. Układają się one w następującą sekwencję:

1) Plac wejściowy przy ul. Bohaterów Monte Cassino, leżący na osi ul. Kardynała Wyszyńskiego - jest przestrzenią publiczną półotwartą o charakterze reprezentacyjnym. Stąd prowadzą monumentalne schody na płytę nad torami, które mogą stać się widownią podczas organizowanych tam imprez;

2) Plac na wyniesionej platformie, ograniczony ścianą ZCK i budynkiem starego dworca, otwarty widokowo na miasto, jest jednocześnie przedłużeniem parku; 
3) Plac przed budynkiem starego dworca zaprojektowano jako element wspólny na pograniczu dwóch obszarów: przestrzeni ZCK i nowej dzielnicy miasta.

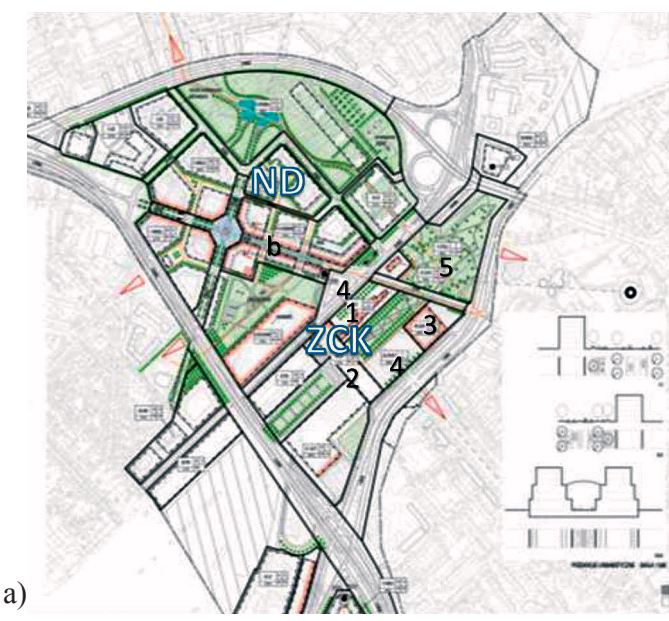

ZCK - obszar Zintegrowanego Centrum Komunikacyjnego: 1. Budynek historycznego dworca PKP

2.Nowy dworzec kolejowy i autobusowy zintegrowany z centrum kongresowym

3.Obiekt administracji lokalnej i terytorialnej

4. Plac

5. Platforma nad torowiskiem - park miejski ND - Nowa Dzielnica, mix development

b-zadaszony pasaż handlowy, kontynuacja historycznej osi śródmiejskiej

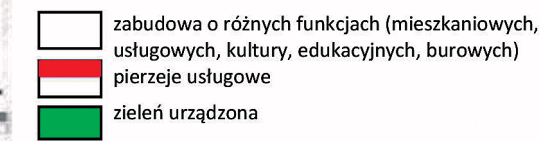

b)
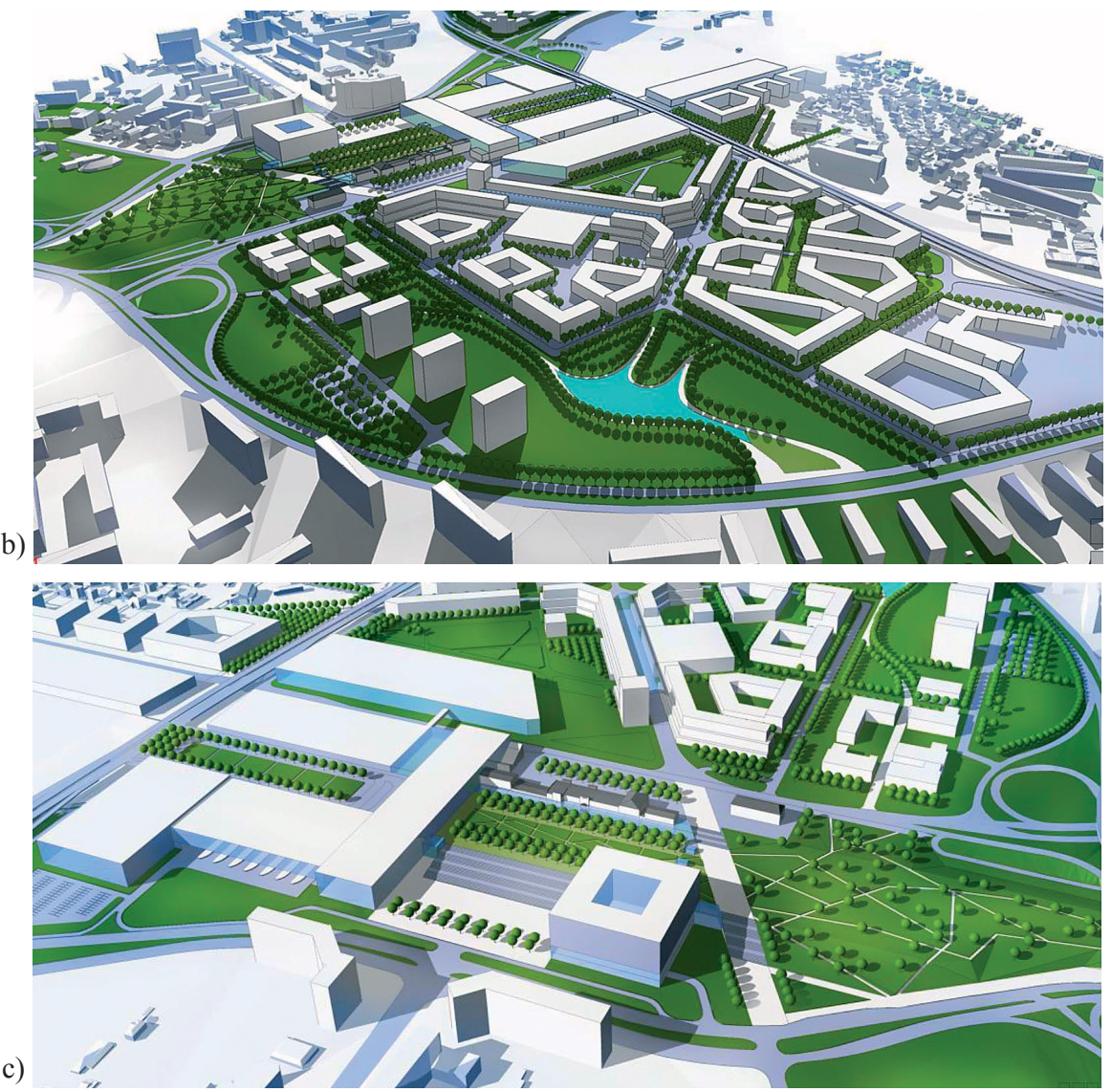

Rys. 4a,b,c. Praca nr 3: a) plan zagospodarowania Obszaru z głównymi elementami koncepcji ZKC; b) koncepcja urbanistyczna Obszaru; c) koncepcja przestrzenna ZCK 
Kompozycja urbanistyczna ZCK jest trudna do scharakteryzowania, ponieważ wymyka się znanym typologiom. Łączy w sobie elementy monumentalnych założeń miejskich i krajobrazowych założeń parkowych. Tym niemniej wpisuje się w szerszy kontekst urbanistyczny, honorując istniejące osie widokowe i dominanty oraz projektowany układ komunikacyjny.

\section{Kierunki przekształceń obszaru przylegającego do ZCK}

Obszar po zachodniej stronie torów przeznaczono na nowoczesną dzielnicę miejską, w której realizowana jest zasada mix development, czyli przemieszanie funkcji rezydencjalnych z usługami handlowymi, kulturalnymi, edukacyjnymi. Zlokalizowano tu (świadomie ograniczając powierzchnie handlowe w ramach ZCK) główne centrum handlowe z wielosalowym kinem, które wytworzy nowy węzeł aktywności przekształcanego obszaru. Nadano mu formę ulicy handlowej - zadaszonego pasażu na śladzie ulicy Zwycięstwa. Ulicę zamknięto dla ruchu samochodowego, a pod jej płytą zlokalizowano parkingi podziemne, strefę dostaw i magazyny. Autorzy uznali, że taka forma przestrzeni handlu(...) jest konkurencyjna w stosun$k u$ do istniejacych galerii handlowych $w$ mieście $i$ wnosi dodana wartość dla rozwoju miasta. [11] W programie użytkowym dzielnicy zaplanowano także wielosalowe kino, aquapark, zielone tereny sportowe oraz obiekty kultury w zaadaptowanym zespole budynków fabrycznych.

\section{Powiązania ZCK z otoczeniem i Obszaru z układem śródmiejskim.}

1) przykrycie torowiska na odcinku między wiaduktem Dąbrowskiego a projektowaną estakadą, „Płytą Miasta”, na której:

- zaplanowano park miejski będący przedłużeniem terenów zielonych wzgórza św. Rocha i parku Dziekońskiej,

- szeroki ciąg pieszo-rowerowy łączący ul. Św. Rocha z ul. Zwycięstwa i szereg innych powiązań;

2) powiązanie obu stron miasta budynkiem nowego dworca strukturalnie związanym z Płytą Miasta;

3) przedłużenie historycznego i funkcjonalnego „kręgosłupa” miasta (ciągu ulic: Rynek Kościuszki, Lipowa, Św. Rocha) o ulicę Zwycięstwa, aż do ul. Jana Pawła II; zaplanowanie ul. Zwycięstwa w konwencji ulicy handlowej.

\section{Podsumowanie i wnioski}

1. Przedstawione w konkursie wizje urbanistyczne i plany zagospodarowania przestrzennego wykazały duży potencjał całego obszaru objętego opracowaniem, a szczególnie jego części po zachodniej stronie linii kolejowej. Przekształcenie obszaru będzie możliwe dzięki uzupełnieniu układu drogowego w tej części miasta o trasę 6KDG, która pokonując tory za pomocą estakady połączy obwodnicę śródmieścia z wylotem w kierunku Warszawy, a także dzięki domknięciu obwodnicy śródmieścia odcinkiem (Bohaterów Monte Cassino Łomżyńska). Realizacja docelowego układu drogowego diametralnie zmienia sytuację części zachodniej, dotychczas zaniedbanej, słabo i chaotycznie zagospodarowanej. Zyskując „granice" i zewnętrzną obsługę komunikacyjną staje się atrakcyjnym terenem inwestycyjnym graniczącym ze śródmieściem.

2. Analiza porównawcza nagrodzonych prac konkursowych pozwoliła zauważyć, że we wszystkich przyjęto podobny kierunek przekształceń terenu po zachodniej stronie torów, proponując utworzenie Nowej Dzielnicy o wybitnie miejskim charakterze, będącej łącznikiem pomiędzy śródmieściem a dzielnicami mieszkaniowymi w zachodniej części miasta. W zaproponowanych planach zagospodarowania Nowej Dzielnicy wystąpiły następujące cechy wspólne: 
a) zastosowano zasadę mix-development i zrównoważenie terenów przeznaczonych na cele mieszkaniowe, komercyjne, rekreacyjne i edukacyjne; w strukturze dzielnicy utrwalono zespół pofabryczny (proponując adaptację na kampus naukowy lub centrum kultury);

b) kręgosłupem urbanistycznym Nowej Dzielnicy (jak i całego Obszaru) była Oś Główna: ul. Św. Rocha-Zwycięstwa-Jana Pawła II, przedłużająca historyczną oś miasta (Rynek Kościuszki - ul. Lipowa - ul. Św. Rocha).

c) Ulica Zwycięstwa (będąca środkowym odcinkiem Osi Głównej) zmienia swój dotychczasowy charakter i staje się główną przestrzenią publiczną dzielnicy. W pracach nadano jej formy: reprezentacyjnego bulwaru, ulicy handlowej lub pasażu handlowego.

3. We wszystkich pracach przyjęto tę samą lokalizację zespołu ZCK i mniej więcej podobny zarys zajmowanej powierzchni. We wszystkich honorowano wynikające z kontekstu zasadnicze elementy kompozycji urbanistycznej (osie widokowe, osie historyczne, gabaryty zabudowy). Natomiast w każdej z prac zaproponowano odmienną koncepcję urbanistyczno -architektoniczną ZCK, na tyle charakterystyczną, że sami Autorzy określali ją hasłowo: np. Brama Dworcowa, Płyta Miasta.

4. Koncepcje programowo-funkcjonalne ZCK różniły się: proporcjami powierzchni dworcowych w stosunku do komercyjnych, stopniem ich zintegrowania funkcjonalno-przestrzennego oraz rodzajem funkcji nie-dworcowych.

Możemy tu mówić o pewnych modelach czy też zakresach integracji:

I - pełna integracja funkcji dworcowych, tj.: funkcji komunikacyjnych i związanych z obsługą pasażera (kasy, informacja, poczekalnie, toalety), uzupełniona drobnym usługami komercyjnymi (gastronomia, handel) ukierunkowanymi na potrzeby podróżnych. Funkcje komercyjne są dodatkiem do funkcji zasadniczych. Taki model wystąpił w pracy nr 1 .

II - jak I + rozszerzenie programu komercyjnego, najczęściej w zakresie handlu i gastronomii, o ofertę skierowaną zarówno do mieszkańców miasta jak i podróżnych;

III - jak II + rozszerzenie programu komercyjnego o funkcje służące kulturze, rozrywce, rekreacji adresowane przede wszystkim do lokalnej ludności (model zbliżony do galerii handlowej). Taki model wystąpił w pracy nr 2.

IV - jak II lub III + komercyjna część biznesowa kongresowo-wystawowa-hotelowa i/lub biurowa. Taki model wystąpił w pracy nr 3 .

5 Niezależnie od powyższych różnic, we wszystkich koncepcjach przestrzennych ZCK funkcje połączonych dworców autobusowego i kolejowego mieściły się we wspólnej bryle (lub bloku funkcjonalnym) zlokalizowanej w miejscu obecnego dworca PKS i przedłużonej o część przerzuconą nad torami. Usytuowanie dworca prostopadłe do układu torowego jest najbardziej korzystne dla organizacji ruchu pasażerów

6. Koncepcje urbanistyczne ZCK różniły się ukształtowaniem przestrzeni publicznych w części ,śródmiejskiej”, przy ul. B. Monte Cassino, natomiast były zgodne co do tego, że Plac Dworcowy przy ul. Kolejowej przed budynkiem historycznego dworca (aktualnie będący parkingiem) powinien być przekształcony w przestrzeń miejską bez ruchu kołowego, przyjazną pieszym, zintegrowaną z Nową Dzielnicą. W 2 pracach proponowano by stała się wręcz ,salonem miasta” związanym z funkcjami gastronomicznymi i kulturalnymi otaczającej zabudowy.

7. We wszystkich pracach szczególny nacisk położono na kwestie połączenia: dwóch części miasta rozdzielonych torami kolejowymi, Nowej Dzielnicy ze Śródmieściem, ZCK z otoczeniem. Proponowano: 
1) połączenie szeroką kładką pieszo-rowerową ulic Św. Rocha i Zwycięstwa,

2) powiązanie kładką pieszo-rowerową obszarów zieleni zlokalizowanych po przeciwnych stronach torów kolejowych: parku im. J. Dziekońskiej u stóp wzgórza kościoła Św. Rocha, z projektowanym ciągiem zielonym i parkiem Nowej Dzielnicy;

3) powiązanie strukturą nowego dworca kolejowo-autobusowego, a konkretnie obszernym pasażem przewieszonym nad peronami kolejowymi, który ze względu na publiczną dostępność obiektu może stać atrakcyjnym przejściem na druga stronę miasta,

4) przykrycie torowiska płytą i scalenie Śródmieścia z Nową Dzielnicą Parkiem Miejskim;

5) przedłużenie historycznego i funkcjonalnego „kręgosłupa” miasta (ciągu ulic: Rynek Kościuszki, Lipowa, Św. Rocha) aż do ul. Jana Pawła II i nadanie ulicy Zwycięstwa rangi reprezentacyjnej przestrzeni publicznej.

8. Analiza nagrodzonych prac konkursowych pozwoliła dostrzec efekty synergii pomiędzy konstrukcją urbanistyczną miasta a projektem przyszłego ZCK. Związane są one z wpływem atrybutów tejże konstrukcji - w tym przypadku historycznej osi miasta i ciągu przestrzeni publicznych - nie tylko na kształtowanie formy urbanistycznej zespołu ZCK, ale także na kształtowanie struktury przestrzennej Nowej Dzielnicy. Synergiczną relacją zwrotną powinno być uwzględnienie w dalszych opracowaniach planistycznych tych elementów proponowanych rozwiązań urbanistycznych, które powtarzając się we wszystkich pracach konkursowych, dały dowód iż są pożądanym rozwinięciem konstrukcji urbanistycznej miasta.

\section{Literatura:}

[1] Załuski D. Wstęp. Dworzec kolejowy w strukturze miasta. (red. Załuski D.). Urbanista, Warszawa 2006.

[2] Zuziak Z.K. Kolej a racjonalizacja miejskiej struktury przestrzennej-między teoria a praktyka. Dworzec kolejowy w strukturze miasta. (red. Załuski D.). Urbanista, Warszawa 2006.

[3] Bogdaniuk B. Integracyjna rola dworców kolejowych $w$ obshudze transportowej miast i regionów. Dworzec kolejowy w strukturze miasta. (red. Załuski D.). Urbanista, Warszawa 2006.

[4] Mazurkiewicz R. Dworzec i jego otoczenie a infrastruktura kolejowa. Dworzec kolejowy w strukturze miasta. (red. Załuski D.). Urbanista, Warszawa 2006.

[5] Ledwoń S. Współczesne obiekty dworcowe w symbiozie z dworcami kolejowymi. Dworzec kolejowy w strukturze miasta. (red. Załuski D.). Urbanista, Warszawa 2006.

[6] Racoń-Leja K. Wykorzystanie przekrytych przestrzeni publicznych w zespołach towarzyszacych współczesnym węzłom kolejowym w obszarach miejskich - potencjat i zagrożenia. Dworzec kolejowy w strukturze miasta. (red. Załuski D.). Urbanista, Warszawa 2006.

[7] Zuziak K.Z. Projekty rewitalizacji otoczenia dworców i przystanków kolejowych. Rozwój regionalny w Małopolsce nr3/15, Departament Polityki Regionalnej Urząd Marszałkowski Województwa Małopolskiego, 2008.

[8] Regulamin Konkursu urbanistyczno-architektonicznego na opracowanie koncepcji zintegrowanego centrum komunikacyjnego wraz z terenami przyległymi w Białymstoku. Miasto Białystok - Urząd Miejski w Białymstoku, Białystok 2012.

[9] II nagroda równorzędna - praca 004-000300 - WXCA. Część opisowa pracy konkursowej. Materiały Urzędu Miejskiego w Białymstoku 2012, płyta CD.

[10] II nagroda równorzędna - praca 005-871228 - 22ARCHITEKCI. Część opisowa pracy konkursowej. Materiały Urzędu Miejskiego w Białymstoku, (2012), płyta CD Część opisowa pracy konkursowej. Materiały Urzędu Miejskiego w Białymstoku 2012, płyta CD.

[11] Wyróżnienie - praca023080 Kuryłowicz-Popławski. Część opisowa pracy konkursowej. Materiały Urzędu Miejskiego w Białymstoku, (2012), płyta CD Część opisowa pracy konkursowej. Materiały Urzędu Miejskiego w Białymstoku 2012, płyta CD. 


\title{
Integrated Transportation Centre as integration space and element ,stitching" city structure
}

\author{
Grażyna Dąbrowska-Milewska' ${ }^{1}$ Bartosz Czarnecki ${ }^{2}$ \\ ${ }^{1}$ Department of Housing Architecture, Faculty of Architecture, Bialystok University of Technology, \\ e-mail: g.milewska@pb.edu.pl \\ ${ }^{2}$ Unit for Urban and Spatial Planning, Department of Housing Architecture, Faculty at Architecture, \\ Bialystok University of Technology, e-mail: b.czarnecki@pb.edu.pl
}

\begin{abstract}
Transportation centers, often located at strategic places of developing cities, surrounded by motorways and parking lots, often shows difficulties in integration with surroundings. Parallel, according to valuable location, they may serve not only for passengers. Their transportation and facility infrastructure, especially that located at pathways integrating both sides of cities, should serve also for other customers. Transportation centers, as mobility and other activity nodes has a great potential to generate synergic results. They may to support neighbor areas development and attractiveness increasing. During the creation of integrated transportation center at the stage of a basic assumption, it is need to include areas of the zone of influence, especially those planned for transformations. Based on 3 cases of projects awarded at the urban-architecture Competition for the idea of the Integrated Transportation Centre with surrounding area in Bialystok, a synergic influence of urban project for surroundings and synergic influence of urban project for urban fabric has been introduced.
\end{abstract}

Keywords: integrated transportation center; urban design; urban project; Bialystok. 